\title{
Amphi-Atlantic phylogeography of direct-developing lineages of Lasaea, a genus of brooding bivalves
}

Received: 17 December 1998 / Accepted: 7 June 1999

\begin{abstract}
Direct-developing intertidal Lasaea spp. occur in the North Atlantic as both continental margin and oceanic island populations. We conducted a molecular phylogenetic analysis of representative populations in order to test colonization hypotheses for North Atlantic oceanic islands. Thirty individuals each were collected in 1995 and 1996 from two continental putative source populations (Florida, Iberia) and two oceanic island populations (Bermuda, Azores). They were sequenced for a 462 nucleotide portion of the mitochondrial large ribosomal subunit (16S) gene. No amphi-Atlantic genotypes were detected: Bermudan lineages co-clustered exclusively with Floridian congeners, and Azorean samples formed an exclusive clade with Iberian haplotypes. Our data indicate that geographical proximity to continental source populations is a better predictor of phylogenetic relationships in North Atlantic Lasaea spp. than present-day oceanic surface circulation patterns. The phylogenetic trees generated are not consistent with colonization of oceanic islands by indirect-developing ancestral lineages or by truly trans-oceanic rafting events. However, they are consistent with predicted topologies resulting from limited $(\leq 2000 \mathrm{~km})$, longdistance colonization by rafting (against present-day circulation patterns in the case of the Azores) and from anthropogenic introductions.
\end{abstract}

Communicated by J.P. Grassle, New Brunswick

D.Ó Foighil $(\bowtie) \cdot$ C.J. Jozefowicz ${ }^{1}$

Museum of Zoology and Department of Biology,

University of Michigan, Ann Arbor,

Michigan 48109-1079, USA

e-mail: diarmaid@umich.edu

Present address:

${ }^{1}$ Division of Biological Sciences,

University of Chicago, Chicago,

Illinois 60637, USA

\section{Introduction}

Oceanic islands are volcanic in origin, have always been separated from continental landmasses by stretches of deep ocean (Nunn 1994), and receive their biotas solely through dispersal (Paulay 1994). Open ocean barriers surrounding such islands constitute dispersal filters for shallow-water benthic marine taxa and biotically insulate island faunas by excluding species incapable of recruiting from distant source populations (Vermeij 1987; Scheltema 1992). Biogeographic studies of benthic marine invertebrate taxa frequently highlight the importance of long-lived pelagic larval stages in attaining a trans-oceanic geographic range that includes oceanic island populations (Kohn and Perron 1994; Emlet 1995; Palumbi et al. 1997; Lessios et al. 1998). Empirical data, however, show that isolated oceanic islands/seamounts are often conspicuously deficient in taxa with feeding pelagic larvae, but not in direct developers (Johannesson 1988; Parker and Tunnicliffe 1994; Davenport and Macalister 1996). There are also numerous nearshore examples of individual species (Helmuth et al. 1994; Ó Foighil et al. 1999), clonal taxa (Jackson 1986), and significant fractions of entire faunas (Fell 1962; Ingólfsson 1995) which have apparently extended their ranges across oceanic barriers in the absence of significant pelagic larval development.

Three dispersal hypotheses have been proposed to explain the presence of shallow-water taxa lacking dispersive larvae on oceanic islands. The simplest invokes undocumented human introductions that predate biotic surveys (Carlton and Hodder 1995). Alternately, oceanic islands may have initially been colonized by planktotrophic larvae, with subsequent evolutionary loss of pelagic larval development (Jablonski and Lutz 1983). Finally, spontaneous rafting events, involving the passive transport of sedentary or sessile life-history stages on drifting objects, may act as a potent longdistance dispersal mechanism for major subsections of shallow-water, hard-bottom faunas (Jackson 1986; 
Johannesson 1988; Jokiel 1990; Helmuth et al. 1994; Ingólfsson 1995).

The present study tests the importance of these three dispersal hypotheses in effecting the colonization of North Atlantic oceanic islands (Bermuda, Azores) by direct-developing lineages of Lasaea, a genus of minute, crevice-dwelling, intertidal bivalve molluscs. The biogeography of Lasaea spp. is remarkable in that sexual diploid species with planktotrophic larvae are restricted to the continental margins of the western Pacific whereas direct-developing polyploid clonal lineages (Crisp and Standen 1988; Thiriot-Quiévreux et al. 1989; Ó Foighil and Smith 1995; Ó Foighil and Thiriot-Quiévreux 1991, 1999) have collectively attained a global distribution which includes large numbers of oceanic islands (O Foighil 1989). Mitochondrial gene trees indicate that this global distribution has been achieved over evolutionarily significant timescales and that northeastern Atlantic continental populations are phylogenetically heterogeneous, containing members of the two major Lasaea clades (Ó Foighil and Smith 1995; Taylor and O Foighil unpublished). Molluscan systematists generally recognize one North Atlantic species, Lasaea adansoni (Gmelin) (= L. rubra Montagu; L. bermudensis Bush), common to most North Atlantic rocky shores (Sterrer 1986). This systematic conclusion is based solely on shell characters, which are poor indicators of phylogenetic relationships among clonal, direct-developing

Fig. 1 North Atlantic showing sampling locations used for continental (Florida; Galicia, Spain) and oceanic island (Bermuda; São Miguel, Azores) Lasaea spp. populations. The predominant surface currents of the North Atlantic Gyre are indicated (modified from Gofas 1990)
Lasaea spp. (Ó Foighil and Eernisse 1988; Tyler-Walters and Crisp 1989; Ó Foighil and Smith 1995, 1996).

The oceanic islands of Bermuda and the Azores are influenced by the Gulf Stream System section of the North Atlantic Gyre (see Fig. 1), i.e. both are downstream from putative western continental source populations (Florida, the northern limit of distribution in North America), and upstream from putative eastern continental source populations (Iberia). North Atlantic surface circulation patterns impose a dispersal polarity on the study system which, together with significant differences implicit in the temporal parameters of the competing dispersal hypotheses, has distinct implications for the predicted phylogenetic tree topologies resulting from each proposed dispersal mechanism.

If Lasaea spp. were absent from these islands until introduced by historical human activity, the genetic structure of island populations would be characterized by a lack of unique genotypes and/or occurrence of Iberian genotypes on either of the upstream oceanic island groupings. The hypothesis of colonization by ancestral planktotrophic larvae assumes that gene flow among the study sites ceased with the independent losses of pelagic larval development in continental and oceanic island populations. It predicts a distinctive phylogenetic topology in which North Atlantic genotypes will resolve into a series of well-defined, genetically distinct clades, each composed of lineages from a geographically discrete region, which form exclusive monophyletic groupings. Based on present-day circulation patterns, the hypothesis of transoceanic colonization by rafting predicts that intermittent gene flow has occurred, over evolutionarily significant timeframes, from western continental margin source populations to both Bermuda and the Azores. Island lineages are predicted to form a clade with Floridian congeners, and to contain unique genotypes exhibiting

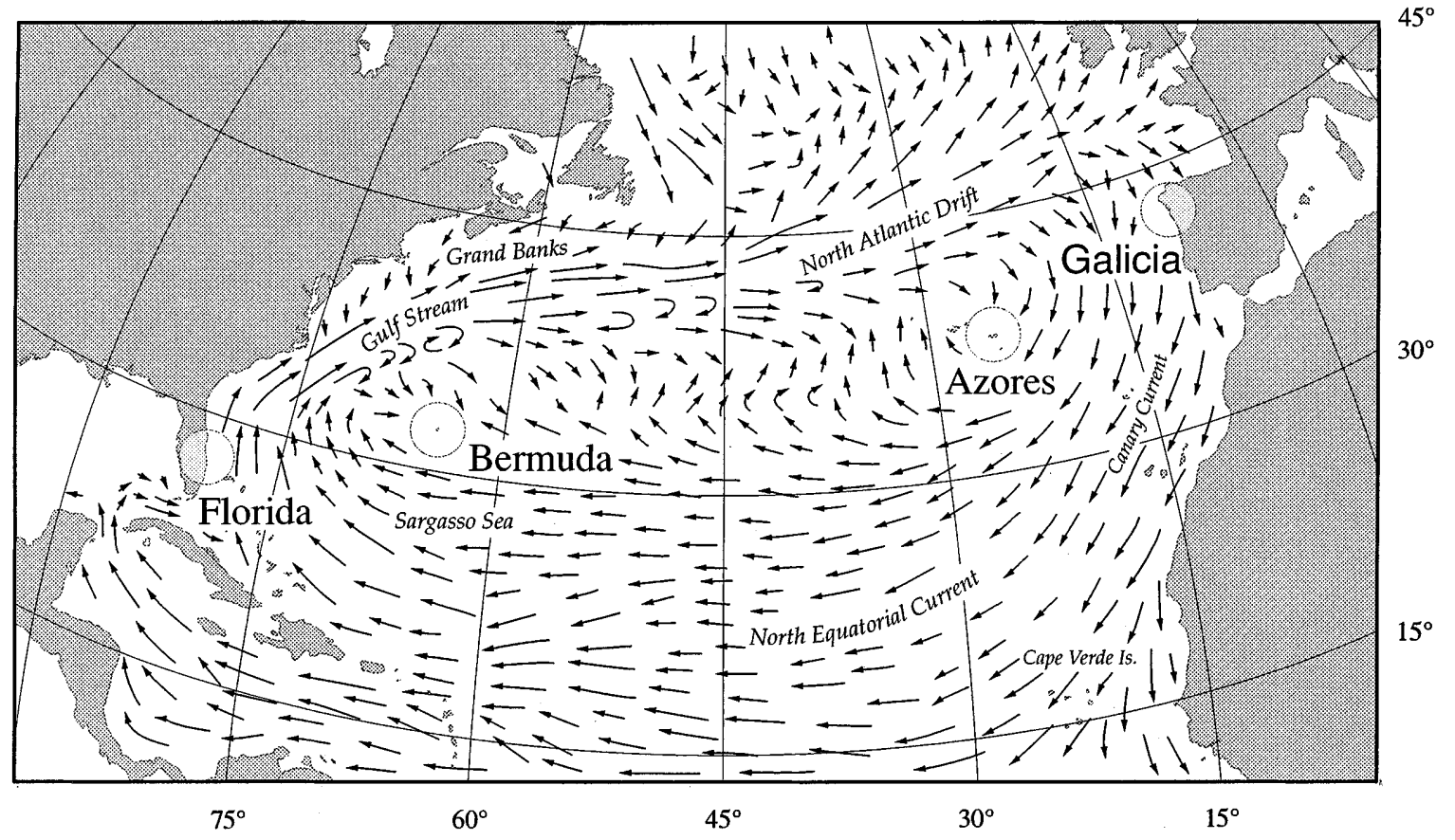


low (Bermuda) to moderate (Azores) levels of divergence from co-clustering western continental congeners.

We tested these three dispersal hyopotheses for North Atlantic Lasaea spp. by constructing phylogenetic trees based on sequence variation in a 462 nucleotide portion of the mitochondrial large ribosomal subunit (16S) gene. Exemplar haplotypes were further characterized for a $624 \mathrm{nt}$ portion of an additional mitochondrial gene, cytochrome oxidase subunit III, in order to place the North Atlantic results in a global phylogenetic perspective (O Foighil and Smith 1995; Taylor and O Foighil unpublished).

\section{Materials and methods}

Specimens of direct-developing Lasaea spp. were sampled from rocky shore, mid-zone intertidal crevices at the four North Atlantic study locations (Fig. 1). Collections were taken in: March 1995 from Lichina pygmaea tufts at Aguiño, Ria de Arousa, Galicia, Spain; April 1995 from coralline algal mats in Vila Franco do Campo, São Miguel, Azores; April 1996 from among barnacles and vermetid gastropods in Phil Foster Park, West Palm Beach, Florida, USA; and May 1996 from among the byssal threads of the mussel Brachidontes domingensis at Flatts Inlet bridge, Bermuda. In each case, clams were taken from a number of microsites on the shore and pooled, prior to fixation in $95 \%$ ethanol, in order to obtain a representative sample of genetic diversity from the study population. The outgroup taxon, Kellia laperousi (Deshayes), had previously been obtained from Indian Arm, Vancouver, British Columbia, Canada (Ó Foighil and Smith 1995).

Thirty individuals from each of the four study populations were genetically characterized by amplifying and directly sequencing a homologous fragment (462 nt) of the mitochondrial (mt) large ribosomal subunit (16S) gene. A subsample of representative $16 \mathrm{~S}$ genotypes was additionally sequenced for a $624 \mathrm{nt}$ fragment of another mt gene, cytochrome oxidase III (CO III), in order to place the North Atlantic lineages into a global phylogenetic framework (O Foighil and Smith 1995). The latter process required cloning of the amplified CO III fragments (a thymidine run of 11 nucleotides within this gene fragment in some North Atlantic haplotypes causes obvious frameshift errors during the amplification cycles), an impractical procedure for our target data set of 120 individuals. Details of the molecular techniques used for generating, $16 \mathrm{~S}$ and CO III sequencing templates are respectively available in O Foighil et al. (1996) and O Foighil and Smith (1995). Both strands of the target fragments were cycle-sequenced using a DNA sequencing kit (PE Applied Biosystems Inc.) and electrophoresed on an ABI 377 automated DNA sequencer. O Foighil et al. (1998) provide methodological details of sequence alignment, phylogenetic analyses, and assessment of branch support levels.

\section{Results}

Fifteen $\mathrm{mt}$ 16S genotypes were encountered among the 120 individuals of direct-developing Lasaea spp. typed from the four North Atlantic study populations (Table 1; Fig. 2). Genetic diversity levels were low in western Atlantic (Florida, Bermuda) samples: a total of four haplotypes differing by a maximum of four substitutions $(1.1 \%)$ for two Bermudan lineages, BDb and BDc, (Tables 1, 2; Fig. 2). All 30 Florida specimens were monomorphic and differed from the rarest of the three
Table 1 Lasaea spp. Distribution of North Atlantic haplotypes among the four study populations. Haplotype prefixes indicate the location from which a mitochondrial genotype was first obtained ( $A Z$ Azores; $I B$ Galicia, Spain; BD Bermuda; FL Florida); 14 of the $15 \mathrm{mt}$ genotypes were restricted to single sites. One haplotype, AZc, occurred in both Azorean and Galician populations

\begin{tabular}{lllll}
\hline \multirow{2}{*}{ Haplotypes } & \multicolumn{4}{l}{ No. per sampling site } \\
\cline { 2 - 5 } & Florida & Bermuda & Azores & Galicia \\
\hline FL & 30 & - & - & - \\
BDa & - & 25 & - & - \\
BDb & - & 4 & - & - \\
BDc & - & 1 & - & - \\
AZa & - & - & 11 & - \\
AZb & - & - & 2 & - \\
AZc & - & - & 3 & 2 \\
AZd & - & - & 12 & - \\
AZe & - & - & 1 & - \\
AZf & - & - & 1 & - \\
IBa & - & - & - & 3 \\
IBb & - & - & - & 17 \\
IBc & - & - & - & 4 \\
IBd & - & - & - & 3 \\
IBe & - & - & - & 1 \\
\hline
\end{tabular}

Bermuda haplotypes, BDc, by only one nucleotide substitution. Azorean and Iberian samples were much more diverse, both in terms of the number of haplotypes (six at each location) and the extent of intrapopulational genetic divergence encountered: up to $7 \%$ and $20.7 \%$, respectively (Tables 1,2 ; Fig. 2). The São Miguel and Galician samples contained the only $\mathrm{mt}$ genotype $(\mathrm{AZc})$ encountered in more than one sampling location.

Maximum parsimony phylogenetic analysis of the North Atlantic 16S mitochondrial dataset yielded five most parsimonious trees which differed only in the relative placement of the four western Atlantic haplotypes at the terminal tips of the trees. A strict consensus is shown in Fig. 3, and two robustly supported clades are evident. One of these clades is exclusively composed of Azorean and Iberian lineages, encompassing 10 of the 11 haplotypes obtained from these populations. These ten Azorean/Iberian haplotypes form three well-differentiated subclades differing by a minimum of $4.7 \%$ in sequence divergence from each other (Fig. 2; Table 2). An exclusively Azorean grouping (AZd-f) may represent an endemic radiation and occupies the basal position in this clade, although this topological placement is relatively weakly supported (decay index value of 1). Haplotypes $\mathrm{IBb}$ and IBe form an exclusively Iberian subclade which is sister to a mixed São Miguel/Galician assemblage $(\mathrm{AZa}-\mathrm{c}, \mathrm{IBa}, \mathrm{c})$. The latter subclade has lineages from both São Miguel and Galicia as terminal taxa (including haplotype AZc which occurs in both locations), however, the basal position is occupied by a mainland $\mathrm{mt}$ genotype, IBa.

The other mt $16 \mathrm{~S}$ clade of North Atlantic Lasaea spp. contains one of the Galician haplotypes, IBd (in a basal position) in addition to the four western Atlantic hap- 


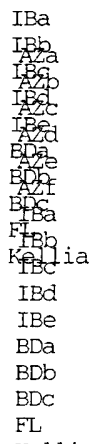

Kellia

AZa
AZb
AZc
AZd
AZe
AZf
IBa
IBb
IBC
IBd
IBe
BDa
BDb
BDC
FL

Kellia

AZa

$A Z b$

AZC

AZa

Aze

AZf

IBa

IBC

IBd

IBe

$\mathrm{BDa}$

$\mathrm{BDb}$

Kellia

AZa

AZb

AZC

AZd

Aze

IBa

IBb

IBC

$\mathrm{Be}$

$\mathrm{BDa}$

BDb

BDC

Kellia

AZa
AZb
AZC
AZd
AZe
AZf

....G...

TTAGTAGATT TATAATTARG GGTCGGGCCT GACCAGTGAT TAATTAACG GCIGCAATTA ATAGThGTGC TA

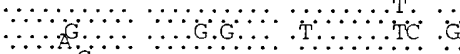

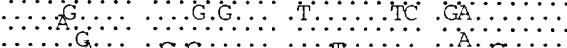

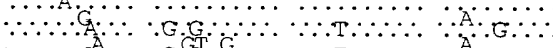

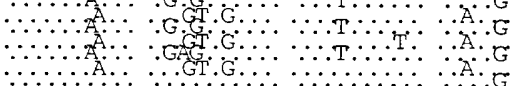

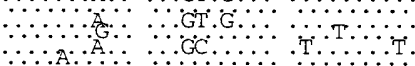

$A G G$.
$\therefore$ G
$\therefore A G . G$

$\therefore A$

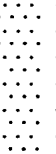

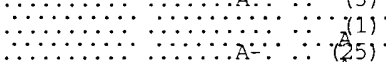

$\because(3) \cdots \cdots$

GBH 112270

100

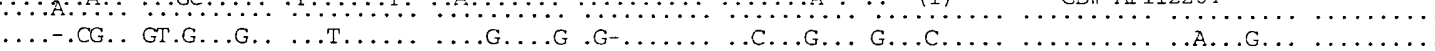

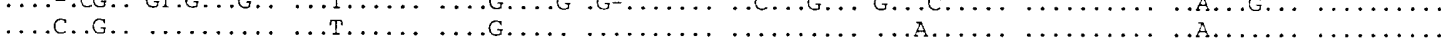

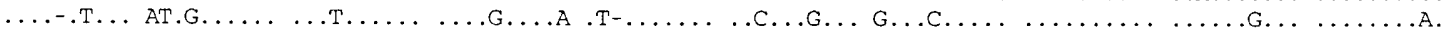

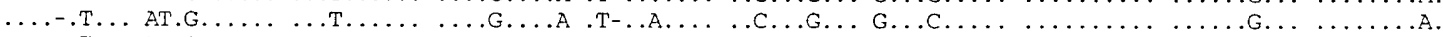

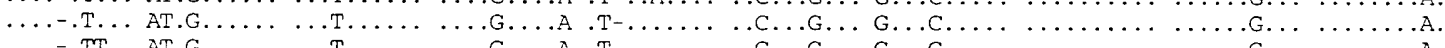

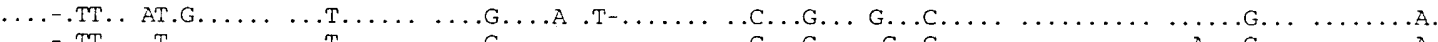

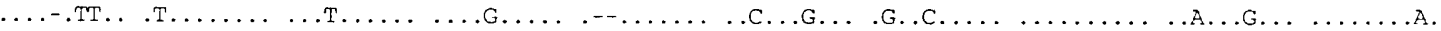

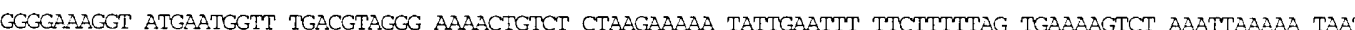

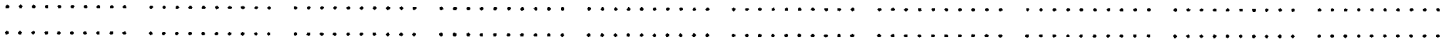

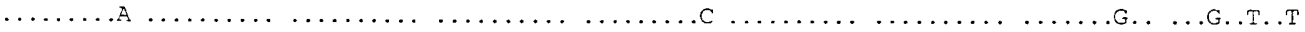

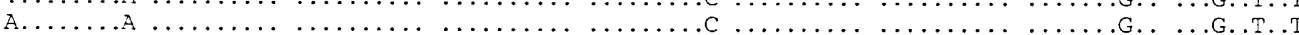

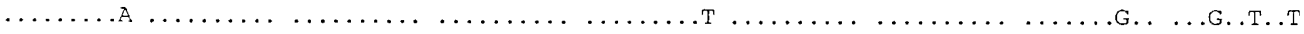

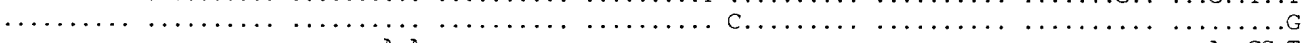

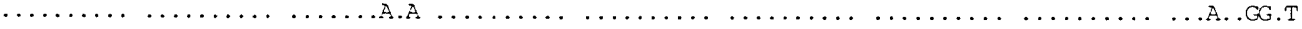

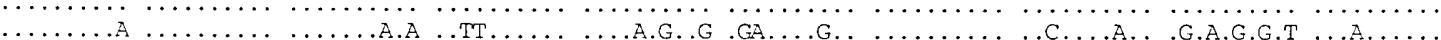

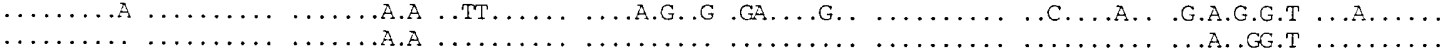

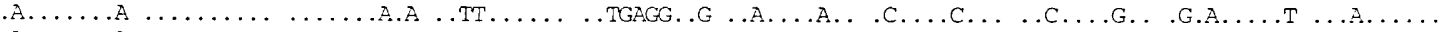

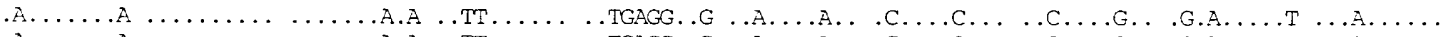

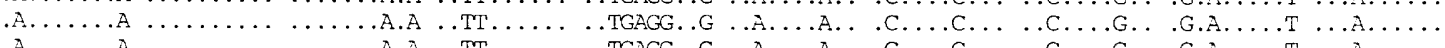

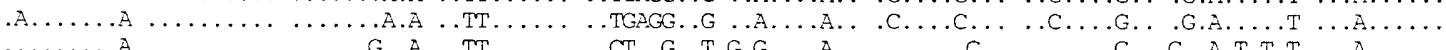

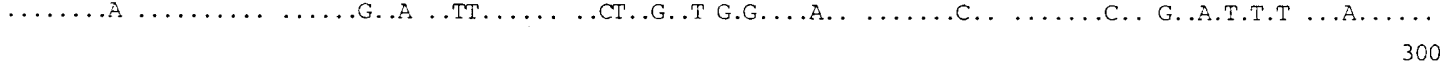
GAAGTCCCTT TCGAGCTTAA TTAAAAGgTA AATAATATTA TTTTMAAAAT TTGGTTGGGG CAACTTAGGA ATAAAAATAG CTTCCTT-AT GATTATATTG

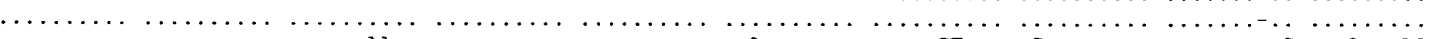

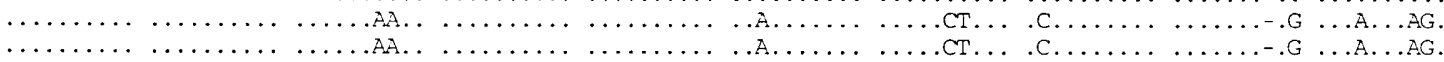

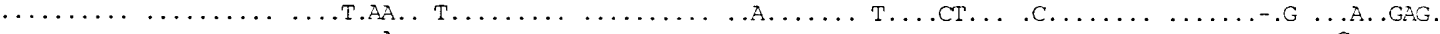

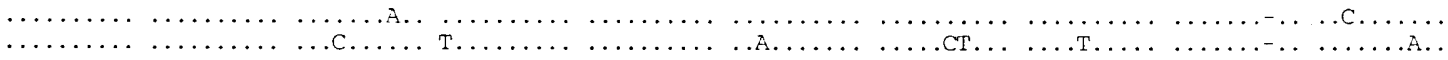

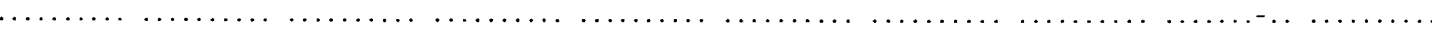

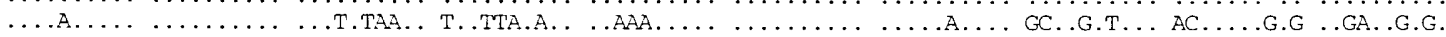

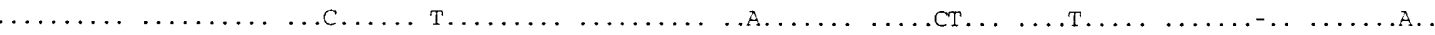

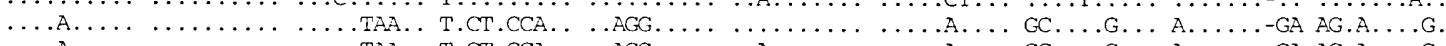

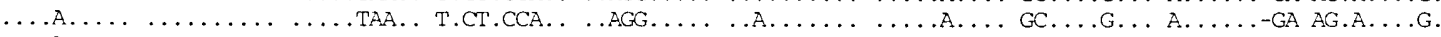

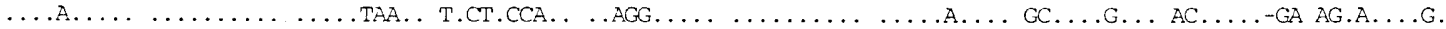

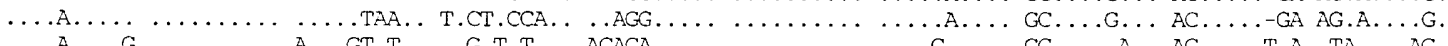

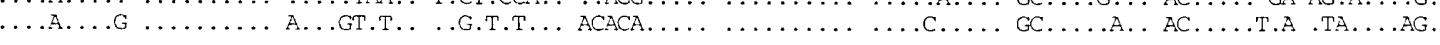

ATCCAAAATT TTMGAA-TAA AGAAAAAGCT ACCGTAGGGA TAACAGCGTT ATCTTTTCTG AGAGAACAAA TTGAaGAAAG GGTTTGCGAC CTCGATGTTG

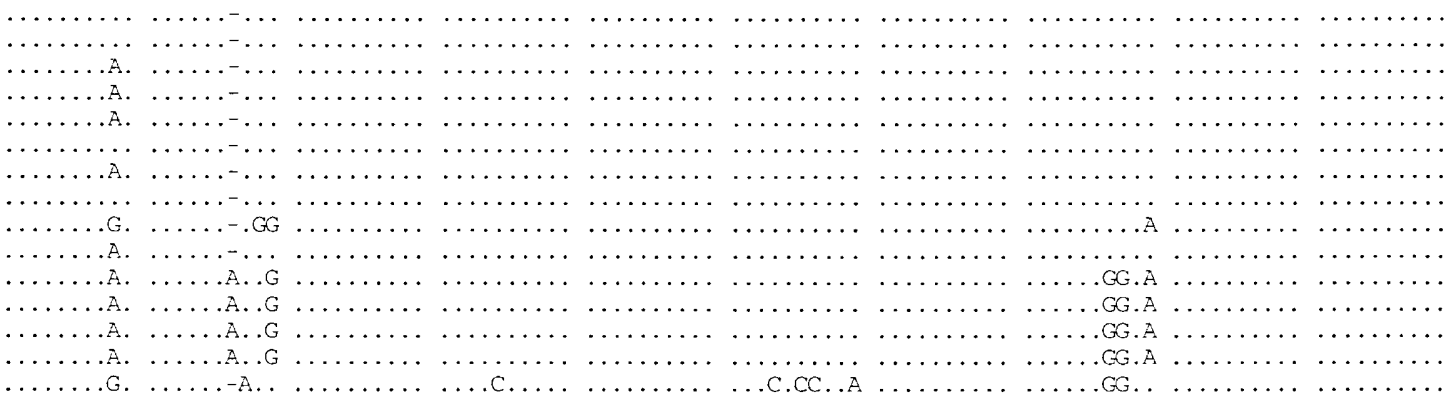

$\ldots \ldots$

462

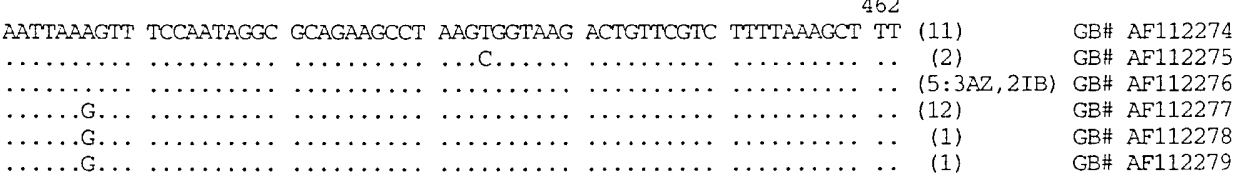


Fig. 2 Lasaea spp. Alignment of the 15 mitochondrial genotypes obtained by sequencing 462 homologous nucleotides of the 16S rDNA gene for 120 individuals, together with one individual of the outgroup Kellia laperousi. Dots indicate nucleotide identity to the first sequence presented, AZa, and inferred nucleotide substitutions relative to AZa are shown, as are inferred insertion/deletion events (-). Prefixes indicate the location from which a mitochondrial genotype was first obtained ( $A Z$ Azores; $I B$ Galicia, Spain; $B D$ Bermuda; $F L$ Florida). The number of individuals encountered per haplotype for each population sample is indicated in brackets at the end of each sequence, preceding its GenBank accession number

lotypes (FL, BDa-c) which form a robustly supported shallow polytomy. IBd is genetically highly differentiated (Table 2) from both the western Atlantic mt genotypes ( $>12.5 \%$ sequence divergence) and from all other Iberian/Azorean haplotypes $(>18 \%$ sequence divergence).

To place the North Atlantic 16S mt genotypes into a global perspective, representative $\mathrm{mt}$ lineages (FL, AZa, $\mathrm{AZe}, \mathrm{IBd}, \mathrm{IBe}$ ) were further characterized for a $624 \mathrm{nt}$ portion of an additional $\mathrm{mt}$ gene, $\mathrm{CO}$ III, and added to a preexisting CO III dataset containing homologous sequences from Pacific and Indian Ocean congeners (O Foighil and Smith 1995; Taylor and O Foighil unpublished). Fig. 4 shows that two mitochondrial clades, containing the same combinations of North Atlantic lineages obtained for 16S (Fig. 3), are also recovered by phylogenetical analysis of the CO III dataset. Although IBd still co-clusters with the western Atlantic exemplar haplotype (FL), the latter forms a robust sister grouping with a direct-developing polyploid congener from Australia (LRAUSDD), and is nested within both a Japanese direct-developing congener (JP4) and the Australian diploid indirect-developing Lasaea australis. This polyploid direct-developing clade (JP4, LRAU SDD, FL) may represent an independent loss of planktonic larval development and diploidy within the genus (Ó Foighil and Smith 1995; Taylor and Ó Foighil unpublished), followed by independent global dispersal of descendant lineages. IBd differs by one nucleotide substitution in its CO III sequence from an Irish clone (IR2) and remains in a basal position relative to L. australis and western Atlantic congeners.

The other North Atlantic lineages from the Azores and Galicia co-cluster with previously studied northeastern Atlantic mt genotypes (Ó Foighil and Smith 1995; Taylor and Ó Foighil unpublished). Lineages $\mathrm{AZa}, \mathrm{AZe}$ and IBe are nested within a robust northeastern Atlantic clade (Fig. 4) which additionally includes Irish (IR), and French Mediterranean (FRMED) haplotypes. Haplotype AZe, which represents a putative endemic Azorean clade (AZd-f, Fig. 3), is sister to mainland lineage IBe but is genetically differentiated ( $>9 \%$ for CO III) from northeastern Atlantic continental lineages (IR1, IR3, FRMED, IBe).

\section{Discussion}

Our results for North Atlantic Lasaea spp. are broadly consistent with the predominant biogeographic ties of the two North Atlantic oceanic island groups. In large part, the Bermudan shallow-water marine fauna is a moderately impoverished extension of the Caribbean coral reef fauna, and there is little evidence for significant species endemism (Warmke and Abbott 1961; Sterrer 1986). Unlike Bermuda, the Azorean marine fauna contains a large number of endemic species (Gofas 1990). However, the great majority of Azorean marine molluscs are part of the regional "Macaronesian" faunal assemblage and have clear phylogenetic ties to the European/ North African nearshore taxa (Gofas 1990; Gosliner 1990; Lee and Vacquier 1995; De Wolf et al. 1998).

Bearing in mind the sampling limitations imposed by the geographic scope of this study, our molecular dataset allows a preliminary evaluation of the competing colonization hypotheses for North Atlantic oceanic island Lasaea spp. Neither Bermudan nor Azorean

Table 2 Lasaea spp. Pairwise sequence divergences among 15 haplotypes characterized for a 462 nucleotide mt $16 \mathrm{~S}$ rDNA fragment. DNA sequence divergence estimates were calculated using

the Jukes-Cantor model and are given in percentages. Prefixes indicate the location from which a mitochondrial genotype was first obtained ( $A Z$ Azores; IB Galicia, Spain; $B D$ Bermuda; $F L$ Florida)

\begin{tabular}{|c|c|c|c|c|c|c|c|c|c|c|c|c|c|c|c|c|}
\hline & & 1 & 2 & 3 & 4 & 5 & 6 & 7 & 8 & 9 & 10 & 11 & 12 & 13 & 14 & 15 \\
\hline 1 & $\mathrm{AZa}$ & & & & & & & & & & & & & & & \\
\hline 2 & $\mathrm{AZb}$ & 0.0021 & & & & & & & & & & & & & & \\
\hline 3 & $\mathrm{AZc}$ & 0.0021 & 0.0043 & & & & & & & & & & & & & \\
\hline 4 & $\mathrm{AZd}$ & 0.0564 & 0.0587 & 0.0587 & & & & & & & & & & & & \\
\hline 5 & AZe & 0.0587 & 0.0611 & 0.0611 & 0.0021 & & & & & & & & & & & \\
\hline 6 & AZf & 0.0682 & 0.0706 & 0.0706 & 0.0131 & 0.0153 & & & & & & & & & & \\
\hline 7 & $\mathrm{BDa}$ & 0.1739 & 0.1767 & 0.1740 & 0.1603 & 0.1630 & 0.1684 & & & & & & & & & \\
\hline 8 & $\mathrm{BDb}$ & 0.1823 & 0.1851 & 0.1823 & 0.1630 & 0.1658 & 0.1712 & 0.0065 & & & & & & & & \\
\hline 9 & BDc & 0.1767 & 0.1795 & 0.1768 & 0.1630 & 0.1657 & 0.1712 & 0.0021 & 0.0087 & & & & & & & \\
\hline 10 & FL & 0.1795 & 0.1823 & 0.1795 & 0.1657 & 0.1684 & 0.1739 & 0.0043 & 0.0110 & 0.0021 & & & & & & \\
\hline 11 & $\mathrm{IBa}$ & 0.0131 & 0.0153 & 0.0153 & 0.0540 & 0.0564 & 0.0658 & 0.1768 & 0.1851 & 0.1795 & 0.1823 & & & & & \\
\hline 12 & $\mathrm{IBb}$ & 0.0471 & 0.0494 & 0.0494 & 0.0494 & 0.0517 & 0.0564 & 0.1795 & 0.1823 & 0.1823 & 0.1823 & 0.0494 & & & & \\
\hline 13 & $\mathrm{IBc}$ & 0.0043 & 0.0065 & 0.0021 & 0.0611 & 0.0634 & 0.0730 & 0.1768 & 0.1795 & 0.1795 & 0.1823 & 0.0176 & 0.0517 & & & \\
\hline 14 & IBd & 0.2076 & 0.2105 & 0.2078 & 0.1961 & 0.1989 & 0.2018 & 0.1281 & 0.1307 & 0.1255 & 0.1255 & 0.2076 & 0.1877 & 0.2049 & & \\
\hline 15 & $\mathrm{IBe}$ & 0.0494 & 0.0517 & 0.0494 & 0.0517 & 0.0540 & 0.0587 & 0.1792 & 0.1821 & 0.1820 & 0.1820 & 0.0517 & 0.0021 & 0.0517 & 0.1875 & - \\
\hline
\end{tabular}




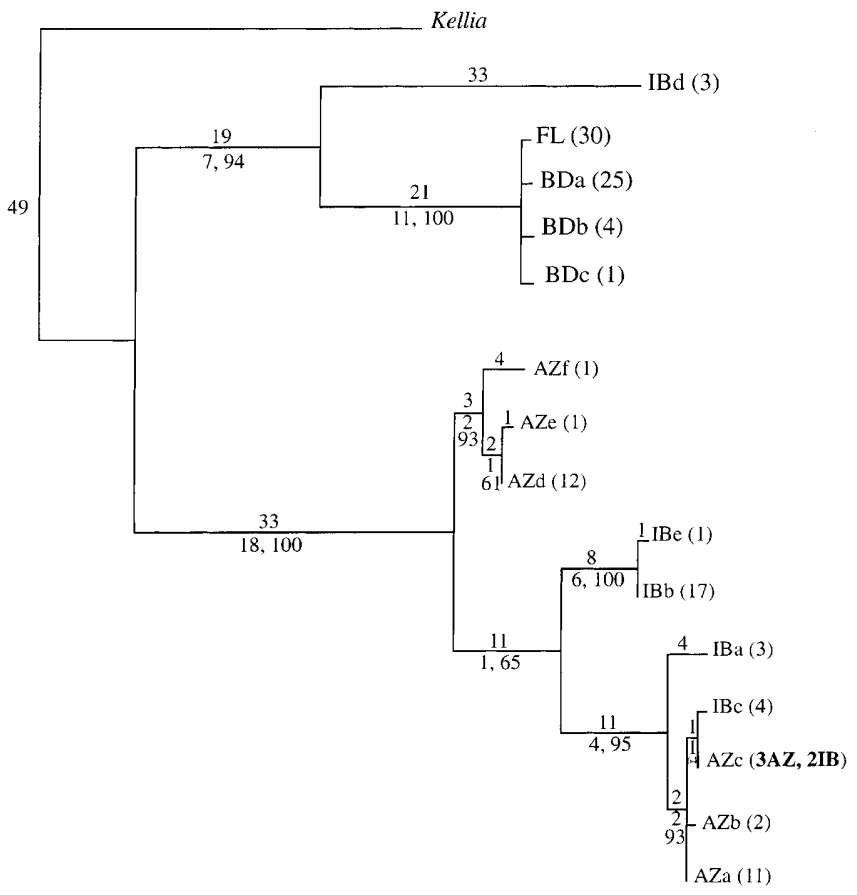

Fig. 3 Lasaea spp. Strict consensus of the five most parsimonious trees (210 steps, $\mathrm{CI}=0.838$, RI $=0.913$ ) obtained by a heuristic search for optimal trees of the mt $16 \mathrm{~S}$ rDNA dataset (Fig. 2), utilizing Kellia laperousi as an outgroup. The respective numbers of steps are indicated above each branch, and the decay index and bootstrap values (500 branch and bound iterations) supporting each node are respectively presented below the branches. Prefixes indicate the location from which a mitochondrial genotype was first obtained ( $A Z$ Azores; $I B$ Galicia, Spain; $B D$ Bermuda; $F L$ Florida) and numbers in parentheses after haplotype labels indicate the number of individuals detected per $\mathrm{mt}$ lineage

samples formed the well-differentiated, island-specific clades predicted by the hypothesis of ancestral colonization by planktotrophic larvae with subsequent loss of pelagic development and off-island recruitment. The closest approximation to this predicted topology is the subset of Azorean lineages (AZd-f; Fig. 3) that form a putative endemic island clade. However, the exemplar $\mathrm{CO}$ III $\mathrm{mt}$ genotype from this grouping, AZe, is nested within a globally distributed, genetically diverse clade that is exclusively composed of direct developers (Fig. 4). Absence of extant North Atlantic indirect-developing Lasaea spp. (Ó Foighil 1989), and phylogenetic placement of both island and putative continental source populations within globally distributed clades of direct developers, seriously undermine the hypothesis of ancestral colonization of the North Atlantic oceanic islands by pelagic larvae.

Our molecular data show mixed support for the hypothesis of transoceanic colonization by rafting. The Bermudan samples have close phylogenetic links to, but are genetically distinct from, Floridian specimens. This pattern of genetic structuring is consistent with rafting hypothesis predictions and is also shown by Caribbean/ Bermudan populations of species with relatively short pelagic larval periods (Mitton et al. 1989), but not by

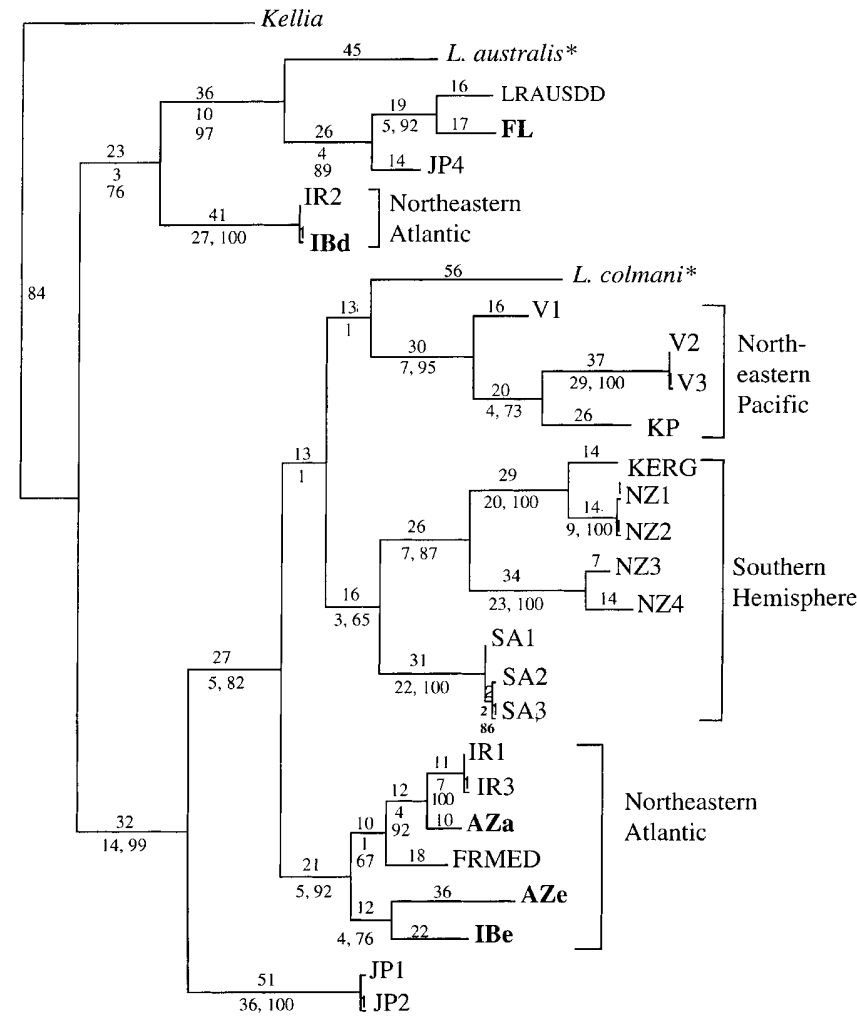

Fig. 4 Lasaea spp. The most parsimonious tree (990 steps, $\mathrm{CI}=0.457, \mathrm{RI}=0.681$ ) obtained by a heuristic search for optimal trees (PAUP) using mt CO III partial sequences (624 nt) from a representative subsample of North Atlantic Lasaea lineages [AZa (GB\# AF112280), AZe (GB\# AF112281), FL (GB\# AF112284), IBd (GB\# AF112282), IBe (GB\# AF112283)], together with a homologous data set from previously studied global Lasaea populations (Ó Foighil and Smith 1995; Taylor and Ó Foighil unpublished). Kellia laperousi was employed as an outgroup and the two known sexual diploid Australian species, L. australis and L. colmani, are indicated by asterisks. The sampling origins of previously studied clonal, polyploid, direct-developing lineages are as follows: LRAUSDD (Australia), JP (Japan), IR (Ireland), FRMED (French Mediterranean), KERG, (Kerguelen Island, southern Indian Ocean), NZ (New Zealand), SA (South Africa), V1-3 and KP (British Columbia, Canada). The respective numbers of steps are indicated above each branch, and the decay index and bootstrap values supporting each node are respectively presented below the branches

species with extended pelagic larval development (Hateley and Sleeter 1993). Surprisingly, the 30 Floridian specimens were monomorphic for the $16 \mathrm{~S}$ gene fragment, and it is not clear how representative they are of overall regional Lasaea spp. genetic diversity in southern Florida/Bahamian putative source populations. If rafting, over evolutionarily significant timescales, does indeed explain the presence of Lasaea spp. on Bermuda, then we predict that genetic characterization of further continental margin (Florida, Bahamas) and Bermudan populations (ideally for a faster evolving gene) would reinforce the genetic distinctiveness of the Bermudan lineages. Alternatively, significant erosion, or loss, of this apparent genetic distinctiveness would leave open the possibility of a predominant role for humanmediated introduction. 
Our phylogenetic results are incompatible with one of the major predictions of the transoceanic rafting hypothesis: placement of Azorean lineages within a western Atlantic clade. Despite lying downstream from potential western continental source populations, the Azorean haplotypes exclusively cluster with Iberian lineages. Although the Azores are less than $2000 \mathrm{~km}$ from the nearest point in North America (Newfoundland), the effective distance from putative Floridian/Bahamian source populations along the Gulf Stream System exceeds $4000 \mathrm{~km}$ (Gofas 1990). The distances involved may be too great for transport of intact rafting platforms and associated fauna that enter the Gulf Stream System at its source. Alternatively, rare rafted innocula of western Atlantic Lasaea spp. may have repeatedly failed to become established, and/or persist, in the Azores due to unfavorable environmental conditions, e.g. water temperature. Presentday minimal seawater surface temperatures in the Azores $\left(15^{\circ} \mathrm{C}\right)$ are lower than in Bermuda $\left(18^{\circ} \mathrm{C}\right.$, Thurman 1997) and are estimated to have reached $12{ }^{\circ} \mathrm{C} 18000$ years ago during late Quarternary glacial cycles (Keffer et al. 1988). This may be pertinent because Floridian/ Bermudan Lasaea spp. belong to a global clade of warmtemperate/sub-tropical direct developers found also in Australia and southern Japan (Fig. 4).

Presence of two distinct clades on São Miguel (Fig. 3), which nest within a regional northeastern Atlantic clade (Fig. 4), is consistent with a minimum of two separate colonization events by ancestral eastern Atlantic continental lineages. Crucially, the Azorean members of these two clades show divergent levels of genetic distinctiveness from mainland sister taxa (Fig. 3; Table 2) implying that a pronounced temporal gap may have separated the inferred colonization events. One of these clades $(\mathrm{AZa}-\mathrm{c}, \mathrm{IBa}, \mathrm{c})$ contains a continental basal $\mathrm{mt}$ genotype (IBa), however, its terminal tips encompass both oceanic island and mainland haplotypes including a single haplotype (AZc) common to both Azorean and Galician samples. This topology is consistent with an evolutionarily recent migration of these lineages to the Azores across $>1400 \mathrm{~km}$ of open ocean and against the prevailing surface circulatory patterns in the eastern North Atlantic (Pollard and $\mathrm{Pu}$ 1985; Fig. 1, present study). Initial settlement of the Azores occurred in the early 16th century (Duncan 1972) and it is possible that lineages $\mathrm{AZa}-\mathrm{c}$ were introduced to São Miguel by human-mediated transport within historical times. If anthropogenic introduction is indeed responsible for the presence of these $\mathrm{mt}$ genotypes on São Miguel, then a more comprehensive genetic characterization of Azorean and Iberian Lasaea populations is predicted to uncover additional $\mathrm{mt}$ genotypes that co-occur on this oceanic archipelago and on eastern Atlantic continental sites.

The other clade of São Miguel haplotypes (AZd-f) shows significant levels of genetic divergence from Iberian congeners $(>4.9 \%$ for $16 \mathrm{~S},>9 \%$ for CO III) and may represent an endemic radiation originating from a much earlier colonization event by ancestral eastern Atlantic continental lineages. The most detailed estimates for fossil-calibrated molluscan mtDNA divergence rates are provided by Reid et al. (1996) for 16S and Collins et al. (1996) for cytochrome $b$ (a protein-coding gene). Both studies utilized marine gastropod taxa, however, they obtained quite distinct estimates of molecular divergence rates for these two very different genes. The rates proposed by Reid et al. (1996) for Littorina spp. yield a range of 11 to 20 million years ago, based on $16 \mathrm{~S}$ transitions and transversions respectively, for the divergence of the putative endemic Azorean Lasaea clade $(A Z d-f)$ from Iberian congeners. In contrast, the rate for Nucella spp. (Collins et al. 1996; 2\% $\mathrm{myr}^{-1}$ lineage $^{-1}$ for third-codon transitional differences) yields an estimate of 4.3 million years ago when applied to a pairwise comparison of the AZe and IBe CO III sequences (36 transitions per 208 third-codon positions). The divergence estimate generated by the Collins et al. (1996) rate approximates the geological age estimate of 4 million years ago for the oldest island volcanism on São Miguel (Abdel-Monen et al. 1975; Feraud et al. 1980).

Few of the Azorean endemic marine fauna have been the subject of molecular studies, however; Azorean abalone stocks are genetically distinct from European congeners (Lee and Vacquier 1995), and this is presumably also the case for the bulk of Azorean endemic marine taxa with phylogenetic ties to Europe/North Africa (Gofas 1990; Gosliner 1990; Salas and Gofas 1998). These taxa, together with the putatively endemic Azorean Lasaea spp. clade (haplotypes AZd-f), may predominantly stem from a hypothetical pulse of Pliocene/Pleistocene colonization that may have occurred under different conditions of surface circulation in the eastern North Atlantic. If this interpretation is correct, we predict that the addition of further eastern Atlantic continental and oceanic island Lasaea spp. genotypes to the $\mathrm{mt}$ data-set will act to reinforce the genetic distinctiveness of this putative endemic clade.

Direct-developing Lasaea spp. are prominent members of intertidal crevice faunas on numerous oceanic island groups (Ó Foighil 1989). Although our North Atlantic study focuses on only two of these (Bermuda, Azores), our findings may well have relevance to how these oceanic island populations became established worldwide. If this is indeed the case, it is likely that such Lasaea spp. populations resulted primarily from multiple, independent colonizations by genetically diverse, rafted, direct-developing ancestors, with a possible overlay of human-mediated introductions in some cases.

Acknowledgements We are most grateful for the generous assistance of T. Backeljau, A. Frias-Martins, T. Collins, P. Mikkelsen, M. Byrne, K. Coates, and B. Healy in obtaining samples for this study. J. Megahan helped prepare Fig. 1. D. Graf, Taehwan Lee, and Joong-Ki Park critically read early drafts. We thank three anonymous reviewers for their constructive comments. Support was provided by a National Geographic Research Grant and NSF Award 9617689 to D. Ó Foighil. 


\section{References}

Abdel-Monem A, Fernandez LA, Boone GM (1975) K-Ar ages for the eastern Azores group (Santa Maria, Sao Miguel and the Fornigas islands). Lithos 8: 247-254

Carlton JT, Hodder J (1995) Biogeography and dispersal of coastal marine organisms: experimental studies on a replica of a 16thcentury sailing vessel. Mar Biol 121: 721-730

Collins TM, Frazer K, Palmer AR, Vermeij GJ, Brown WM (1996) Evolutionary history of northern hemisphere Nucella (Gastropoda, Muricidae): molecular, morphological, ecological and paleontological evidence. Evolution 50: 2287-2304

Crisp DJ, Standen A (1988) Lasaea rubra (Montagu) (Bivalvia: Erycinea), an apomictic crevice-living bivalve with clones separated by tidal level preference. J exp mar Biol Ecol 117: 27-45

Davenport J, Macalister H (1996) Environmental conditions and physiological tolerances of intertidal fauna in relation to shore zonation at Husvik, South Georgia. J exp mar Biol Ecol 76: 985-1002

De Wolf H, Backeljau T, van Dongen S (1998) Large scale patterns of shell variation in Littorina striata, a planktonic developing periwinkle from Macaronesia (Mollusca: Prosobranchia). Mar Biol 131: 309-317

Duncan TB (1972) Atlantic islands, Madeira, the Azores and the Cape Verdes in seventeenth-century commerce and navigation. The University of Chicago Press, Chicago

Emlet RB (1995) Developmental mode and species geographic range in regular sea urchins (Echinodermata: Echinoidea). Evolution 49: 476-489

Fell HB (1962) West-wind drift dispersal of echinoderms in the Southern Hemisphere. Nature 193: 759-761

Feraud G, Kaneoka I, Allérge CJ (1980) K/Ar ages and stress pattern in the Azores: geodynamic implications. Earth planet Sci Lett 46: 275-286

Gofas S (1990) The littoral Rissoidae and Anabathridae of São Miguel, Azores. Accoreana 1990 (Suppl): 97-134

Gosliner TM (1990) Opistobranch mollusks from the Azores Islands. I. Runcinidae and Chromodorididae. Açoreana 1990 (Suppl): 135-166

Hateley JG, Sleeter TD (1993) A biochemical genetic investigation of spiny lobster (Panuliris argus) stock replenishment in Bermuda. Bull mar Sci 52: 993-1006

Helmuth R, Veit RR, Holberton R (1994) Long-distance dispersal of a subantarctic brooding bivalve (Gaimardia trapesina) by kelp-rafting. Mar Biol 120: 421-426

Ingólfsson A (1995) Floating clumps of seaweed around Iceland: natural microcosms and a means of dispersal for shore fauna. Mar Biol 122: 13-21

Jablonski D, Lutz RA (1983) Larval ecology of marine benthic invertebrates: paleobiological implications. Biol Rev 58: 21-89

Jackson JBC (1986) Modes of dispersal of clonal benthic invertebrates: consequences for species' distributions and genetic structure of local populations. Bull mar Sci 39: 588-606

Johannesson K (1988) The paradox of Rockall: why is a brooding gastropod (Littorina saxatilis) more widespread than one having a planktonic larval stage (L. littorea)? Mar Biol 99: 507-513

Jokiel PL (1990) Transport of reef corals into the Great Barrier Reef. Nature 347: 665-667

Keffer T, Martinson DG, Corliss BH (1988) The position of the Gulf Stream during Quaternary glaciations. Science 241: 440-442

Kohn AJ, Perron FE (1994) Life history and biogeography patterns in Conus. Oxford Biogeography Series 9, Clarendon Press, Oxford

Lee YH, Vacquier VD (1995) Evolution and systematics in Haliotidae (Mollusca: Gastropoda): inferences from DNA sequences of sperm lysin. Mar Biol 124: 267-278

Lessios HA, Kessing BD, Robertson DR (1998) Massive gene flow across the world's most potent marine biogeographic barrier. Proc R Soc (Ser B) 265: 583-588

Mitton JB, Berg CJ, Orr KS (1989) Population structure, larval dispersal, and gene flow in the queen conch, Strombus gigas, of the Caribbean. Biol Bull mar biol Lab, Woods Hole 177: 356-362
Nunn PD (1994) Oceanic islands. Blackwell, Oxford

Ó Foighil D (1989) Planktotrophic larval development is associated with a restricted geographic range in Lasaea, a genus of brooding, hermaphroditic bivalves. Mar Biol 103: 349-358

Ó Foighil D, Eernisse DJ (1988) Geographically widespread, nonhybridizing, sympatric strains of the hermaphroditic brooding clam Lasaea in the northeastern Pacific Ocean. Biol Bull mar biol Lab, Woods Hole 175: 218-229

Ó Foighil D, Gaffney PM, Hilbish TJ (1998) Mitochondrial gene sequences support an Asian origin for the Portuguese oyster Crassostrea angulata (Lamarck, 1819). Mar Biol 131: 497-503

Ó Foighil D, Hilbish TJ, Showman RS (1996) Mitochondrial gene variation in Mercenaria clam sibling species reveals a relict secondary contact zone in the western Gulf of Mexico. Mar Biol 126: 675-683

Ó Foighil D, Marshall BA, Hilbish TJ, Pino MA (1999) Trans-Pacific range extension by rafting is inferred for the flat oyster Ostrea chilensis. Biol Bull mar biol Lab, Woods Hole 196: 122-126

Ó Foighil D, Smith MJ (1995) Evolution of asexuality in the cosmopolitan marine clam Lasaea. Evolution 49: 140-150

Ó Foighil D, Smith MJ (1996) Phylogeography of an asexual marine clam complex, Lasaea, in the northeastern Pacific based on cytochrome oxidase III sequence variation. Molec Phylogenetics Evolut 6: 134-142

Ó Foighil D, Thiriot-Quiévreux C (1991) Ploidy and pronuclear interaction in northeastern Pacific Lasaea clones. Biol Bull mar biol Lab, Woods Hole 181: 222-231

Ó Foighil D, Thiriot-Quiévreux C (1999) Sympatric Australian Lasaea species (Mollusca: Bivalvia) differ in their ploidy levels, reproductive modes and developmental modes. J Linn Soc (in press)

Palumbi SR, Grabowsky G, Duda T, Geyer L, Tachino N (1997) Speciation and population genetic structure in tropical Pacific sea urchins. Evolution 51: 1506-1517

Parker T, Tunnicliffe V (1994) Dispersal strategies of the biota on an oceanic seamount - implications for ecology and biogeography. Biol Bull mar biol Lab, Woods Hole 34: 134-144

Paulay G (1994) Biodiversity on oceanic islands - its origin and extinction. Am Zool 34: 134-144

Pollard RT, Pu S (1985) Structure and circulation of the upper Atlantic Ocean northeast of the Azores. Prog Oceanogr 14: 443-462

Reid DG, Rumbank E, Thomas RH (1996) DNA morphology and fossils: phylogeny and evolutionary rates of the gastropod genus Littorina. Phil Trans R Soc (Ser B) 351: 877-895

Salas C, Gofas S (1998) Description of four new species of Neolepton Monterosato, 1875 (Mollusca: Bivalvia: Neoleptonidae), with comments on the genus and on its affinity with the Veneracea. Ophelia 48: 35-70

Scheltema RS (1992) Passive dispersal of planktonic larvae and the biogeography of tropical sublittoral invertebrate species. In: Colombo $\mathrm{G}$ et al. (eds) Marine eutrophication and population dynamics. Proceedings of the 25th European Marine Biological Symposium. Oslen and Olsen, Fredensborg, Denmark, pp 195202

Sterrer W (1986) Marine fauna and flora of Bermuda. Wiley and Sons, New York

Thiriot-Quiévreux C, Insua Pombo AM, Albert P (1989) Polyploïdie chez un bivalve incubant Lasaea rubra (Montagu). C r hebd Séanc Acad Sci, Paris 308: 115-120

Thurman HV (1997) Introductory oceanography, 8th edn. Prentice Hall, Engelwood Cliffs, New Jersey

Tyler-Walters H, Crisp DJ (1989) The modes of reproduction in Lasaea rubra (Montagu) and L. australis (Lamarck): (Erycinidae; Bivalvia). In: Ryland JS, Tyler PA (eds) Proceedings of the 23rd European Marine Biological Symposium. Olsen and Olsen, Fredensborg, Denmark, pp 299-308

Vermeij GJ (1987) The dispersal barrier in the tropical Pacific: implications for molluscan speciation and extinction. Evolution 41: $1046-1058$

Warmke M, Abbott RT (1961) Caribbean seashells. Livingston, Narberth, Pennsylvania 